\title{
PENGARUH KUALITAS PELAYANAN DAN HARGA TERHADAP KEPUASAN PELANGGAN JASA TRANSPORTASI ONLINE (GO-JEK)
}

\author{
Musdalifah $^{1)}$ dan M. Fauzan Noor $^{2)}$ \\ ${ }^{1,2}$ Jurusan Pariwisata, Politeknik Negeri Samarinda \\ 1,2,Jl. Cipto Mangunkusumo Kampus Gunung Lipan Samarinda Kaltim \\ E-mail : lmusda14@yahoo.co.id ${ }^{1)}$,m.fauzan_noor@polnes.ac.id ${ }^{2)}$
}

\begin{abstract}
ABSTRAK
Penelitian ini bertujuan untuk mengetahui pengaruh kualitas pelayanan dan harga terhadap kepuasan pelanggan jasa transportasi online (gojek di wilayah sekitaran kecamatan Sungai Kunjang Provinsi Kalimantan Timur dengan responden sebanyak 109 orang. Data dalam penelitian ini dikumpulkan dengan menyebarkan kuisioner terhadap pengguna jasa transportasi online (gojek). Penelitian ini menggunakan dua variabel bebas yaitu kualitas pelayanan dan harga dimana kualitas pelayanan diukur menggunakan lima indikator dan harga diukur menggunakan tiga indikator. Sedangkan variabel terikat kepuasan pelanggan diukur dengan menggunakan Berdasarkan hasil uji yang telah dilakukan menunjukkan bahwa adanya pengaruh kualitas pelayanan dan harga terhadap kepuasan pelanggan baik ketika diuji secar simultan dan parsial. Namun dari kedua variabel bebas ini yang dominan berpengaruh adalah kualitas pelayanan. Berdasarkan hasil penelitian ini dapat ditarik kesimpulan bahwa kualitas pelayanan seiring berjalan dengan harga mempengaruhi kepuasan pelanggan.
\end{abstract}

Kata Kunci: kualitas pelayanan, harga, kepuasan pelanggan, gojek, transportasi online

\section{PENDAhUluAN}

Di era modern ini masyarakat mempunyai aktivitas yang beragam dan untuk memenuhi aktivitas tersebut masyarakat memerlukan adanya transportasi sebagai alat penunjang dalam melakukan aktivitasnya. Oleh karena itu banyak bermunculan perusahaan jasa transportasi yang berlomba-lomba untuk mendapatkan knsumern dengan peningkatan pelayanan, kemudahan pemesan, kenyamanan armada, ketepatan waktu dan sebagainya.

Di Samarinda, moda transportasi yang seringdigunakan adalah sepeda motor, hal ini dikarenakan sepeda motor dapat digunakan untuk mengangkut orang/barang dan memiliki biaya yang cukup terjangkau. Moda transportasi ini dikenal dengan nama ojek.

Seiring dengan berkembangnya teknologi saat ini terdapat aplikasi yang mengenalkan layanan pemesanan ojek. Pada awalnya ojek menggunakan sistem pangkalan pada tempat-tempat tertentu, sehingga ojek dari tempat lain tidak dapat masuk tanpa ijin dari ojek yang ada di tempat tersebut. Namun saat ini bermunculan penyedia jasa ojek online yang dapat memberikan pelayanan yang sama dengan ojek yang ada hanya saja tidak terbatas pada sistem pangkalan.

Semakin banyaknya ojek online yang bermunculan berdampak pada semakin ketatnya persaingan. Faktor yang menjadi penyebab terjadinya hal tersebut yaitu adanya persaingan harga sehingga membuat konsumen dapat memilih jasa ojek online yang pada akhirnya penyedia jasa ojek online harus menciptakan kualitas layanan dan harga yang sesuai agar dapat menciptakan kepuasan pelanggan.

Dalam penelitian ini variabel kualitas pelayanan bergantung pada tiga hal yaitu sistem, teknologi dan sumber daya manusia. Selain kualitas pelayanan dalam penelitian ini juga mengambil harga sebagai salah satu faktor penentu dalam kepuasan pelanggan, hal ini telah dinyatakan dalam penelitian yang telah dilakukan Lenzun, dkk (2014) bahwa harga berpengaruh secara signifikan terhadap kepuasan pelanggan yang mengindikasikan bahwa manajemen perusahaan sebaiknya meningkatkan kualitas produk khususnya kualitas jaringan dengan meminimalisir terjadinya gangguan jaringan dan mempertahankan harga agar sesuai dengan kualitas produk.

Dengan adanya jasa ojek online yang menyediakan beberapa macam layanan yang menekankan pada kemudahan dan tidak perlu dilakukan tawar menawar harga karena harga telah dihitung sesuai dengan jarak tempuh. Dari berbagai jasa layanan jasa ojek yang ada, dalam penelitian ini jasa layanan yang diambil adalah go ride hal ini dikarenakan konsumen merasakan mulai dari pemesanan, penjemputan hingga pada sampai pada tempat tujuan.

Adapun tujuan dalam penelitian ini adalah untuk mengetahui apakah kualitas layanan dan harga bepengaruh terhadap kepuasan konsumen pengguna jasa ojek online. Sejalan dengan tujuan penelitian ini maka manfaat yang diperoleh adalah untuk mengetahui sejauh mana penyedia jasa ojek online dapat memberikan 
kepuasan terhadap penggunanya yang dillihat dari sisi kualitas layanan yang diberikan dan mengenai harga yang sudah ditetapkan sesuai dengan jaraknya.

Luaran yang ingin dicapai dalam penelitian ini adalah mengetahui dan mengukur kepuasan pelanggan yang dilihat dari kualitas pelayanan dan harga. Ketika pelayanan yang diberikan mampu menimbulkan rasa puas terhadap penggunanya maka akan timbul loyalitas. Pelayanan yang berkualitas selalu memperhatikan segala aspek yang berkenaan dengan pelanggannya. Disamping itu harga juga merupakan salah satu faktor penentu dalam mengukur kepuasan pelanggan, ketika apa yang diharapkan pelanggan sesuai dengan yang diinginkan maka harga atau biaya yang dikeluarkan seharusnya sesuai dengan nilai yang diterima oleh pelanggan

Hasil penelitian ini diharapkan nantinya dapat dijadikan referensi sebagai bahan pertimbangan untuk lebih memperhatikan sisi kualitas pelayanan dan harga yang telah ditetapkan demi kepuasan pelanggan. Sebuah perusahaan tidak hanya mementingkan keuntungan yang diperoleh namun ada hal penting yang menjadi tolak ukur keberhasilannya adalah ketika para konsumen (pelanggan) merasa puas akan pelayanan yang telah diberikan karena hal ini lah yang dapat membuat perusahaan dapat bertahan dalam memenangkan kompetisi yang ada.

\section{RUANG LINGKUP}

Berdasarkan latar belakang yang telah diungkapkan maka permasalahan dalam penelitian ini adalah apakah kualitas layanan dan harga berpengaruh terhadap kepuasan konsumen pengguna jasa ojek online?

Hipotesis dalam penelitian ini adalah

1. Kualitas layanan berpengaruh terhadap kepuasan konsumen

2. Harga berpengaruh terhadap kepuasan konsumen

\section{BAHAN DAN METODE}

Penelitian ini adalah penelitian dekriptif kuantitatif, dimana hasil penelitian ini diperoleh dari kuisioner yang telah disebar kepada para pengguna gojek.

\subsection{Kepuasan Pelanggan}

Kotler dan Keller $(2009 ; 139)$ menjelaskan bahwa kepuasan konsumen adalah perasaan senang atau kecewa yang timbul karena membandingkan kinerja yang dipersepsikan produk(atau hasil) terhadap ekspektasi mereka.

Indikator kepuasan konsumen jasa transportasi yaitu(Mardikawati, Woro dan Farida 2013) :

1. Kesesuaian layanan yang diharapkan, dalam hal ini berkaitan dengna persepsi pelanggan apakah kualitas jasa yang diterimanya sesuai atau tidak dengan yang dijanjikan, penyedia jasa terhadap harapan pelanggan.

2. Kesesuaian layanan dengan tarif yang dibayarkan, dalam hal ini berkaitan dengan persepsi pelanggan atas apa yang mereka rasakan, apakah layanan yang mereka terima sesuai dengan biaya atau tarif yang telah mereka bayarkan untuk mengkonsumsi layanan tersebut.

3. Kepuasan pelanggan akan layanan yang ditawarkan, dalam hal ini berkaitan dengan persepsi puas atau tidaknya pelanggan atas layanan yang ditawarkan dibandingkan dengan penyedia jasa lainnya.

\subsection{Kualitas Pelayanan}

Kualitas pelayanan dapat diartikan sebagai upaya pemenuhan kebutuhan dan keinginan konsumen serta ketepatan penyampaiannya dalam mengimbangi harapan konsumen(Tjiptono 2008). Kualitas pelayanan (service quality) dapat diketahui dengan cara membandingkan persepsi para konsumen atas pelayanan yang nyata-nyata mereka terima / peroleh dengan pelayanan yang sesungguhnya mereka harapkan / inginkan terhadap atribut-atribut pelayanan suatu perusahaan. Jika jasa yang diterima atau dirasakan (perceived service) sesuai dengan yang diharapkan, maka kualitas pelayanan dipersepsikan baik dan memuaskan, jika jasa yang diterima melampaui harapan konsumen, maka kualitas pelayanan dipersepsikan sangat baik dan berkualitas. Sebaliknya jika jasa yang diterima lebih rendah daripada yang diharapkan, maka kualitas pelayanan dipersepsikan buruk.

Kualitas adalah totalitas fitur dan karakteristik produk atau jasa yang bergantung pada kemampuaanya untuk memuaskan kebutuhan yang dinyatakan atau tersirat(Kotler and keller 2009).

Kualitas layanan berfokus pada uapaya pemenuhan kebutuhan pelanggan serta ketepatan penyampaian untuk mengimbangi harapan pelanggan. Kualitas layanan dapat dievaluasi dengan cara membandingkan kualitas yang dialami atau diterima pelanggan perusahaan dengan layanan yang diharapkan (Tjiptono 2014).

Dimensi SERVQUAL yang menjadi dasar pengembangan telaah terhadap kualitas pelayanan(Utami 2010), yaitu :

1. Berwujud meliputi fasilitas fisik kelengkapan, karyawan dan saran komunikasi

2. Keandalan yaitu kemampuan memberikan layanan yang dinajnjikan segera, akurat dan memuaskan.

3. Ketanggapan yaitu keinginan para staff untuk membantu pelanggan dan memberikan pelayanan dengan tanggap

4. Kepastian mencakup pengetahuan, kompetensi, kesopanan dan sifat dapat dipercaya yang dimiliki para staff

5. Empati meliputi kemudahan dalam menjalin relasi, komunikasi yang baik, perhatian secara personal dan pemahaman atas kebutuhanindividual para pelanggan. 


\subsection{Harga}

Menurut Kertajaya (2006) dalam (Cahya 2015) indikator dari harga dapat dinyatakan dalam penilaian konsumen terhadap besarnya pengorbanan financial yang diberikan dalam kaitannya dengan spesifikasi yang berupa kualitas produk. Selain itu penilaian harga dapat dilihat dari kesesuaian antara suatu pengorbanan dari konsumen terhadap nilai yang diterimanya setelah melakukan pembelian, dan berdasarkan hal tersebut konsumen akan mempersepsikan dari produk atau jasa tersebut. Persepsi positif adalah hasil dari rasa puas akan suatu pembelian yang dilakukannya, sedangkan persepsi negatif merupakan bentuk dari ketidakpuasan konsumen atas produk atau jasa yang dibelinya. Dari pernyataan tersebut dapat disimpulkan bahwa indikator harga adalah:

1. Kesesuaian harga dengan manfaat yang didapat, yaitu apabila penetapan akan suatu harga produk atau jasa memberikan manfaat yang cukup setara bagi konsumen.

2. Kesesuaian harga produk dengan kualitas produk yatiu dimana harga yang ditetapkan sesuai dengan kualitas produk yang dirasakan oleh konsumen

Ada beberapa indikator dalam mengukur harga yaitu(Tjiptono 2008) :

1. Jangkauan harga dengan daya beli konsumen, yaitu apabila harga yang ditetapkan oleh suatu produk masih dapat dibeli atau dijangkau oleh konsumen (tidak mahal)

2. Daya saing harga dengan produk sejenis, adalah ketika harga yang ditetapkan oleh produk tertentu dapat bersaing di pasaran dengan produk sejenis.

3. Kesesuaian harga dengan kualitas yaitu ketika harga yang ditawarkan kepada konsumen sesuai dengan kualitas yang didapatkan konsumen, barang yang dibeli tidak mudah rusak dan awet dalam jangka waktu lama

\subsection{Metode Penelitian / Tahapan Penelitian}

Penelitian ini dilakukan dengan menyebarkan kuisioner yang memuat daftar pertanyaan/pernyataan mengenai variabel yang diteliti dalam penelitian ini yaitu kualitas pelayanan, harga dan kepuasan pelanggan. Kuisioner disebarkan kepada para penguna jasa gojek khususnya yang menggunakan jasa goride. Kuisioner yang disebar sebanyak 200 namun yang memenuhi kriteria hanya 109 sehingga yang menjadi responden hanya 109 orang yang didasarkan pada kriteria yang telah ditentukan yaitu khusus pengguna goride. Kemudian hasil kuisioner diolah mulai dari karakteristik responden, uji validitas dan reabilitas, uji asumsi klasik, dan uji hipotesis. Alat analisis yang digunakan dalam penelitian ini adalah regresi berganda dengan alat bantu spss versi 18.

Adapun tahapan dalam penelitian ini adalah :

1. Tahap pendahuluan yang dilakukan dengan mengadakan observasi secara langsung terhadap para pengguna gojek
1. Identifikasi masalah, hal ini dilakukan untuk mendapatkan gambaran mengenai masalah hingga pada solusi atas permasalahan yang ada.

2. Studi literatur, hal ini dimaksudkan agar terkait dan berhubungan dengan masalah yang ada dalam penelitian ini.

2. Penentuan variabel penelitian

Dalam penelitian ini variabel yang digunakan menggunakan variabel bebas dan terikat. Variabel bebas terdiri atas kualitas pelayanan dan harga sedangkan variabel terikatnya adalah varibel kepuasan. Variabel. Variabel kualitas pelayanan diukur menggunakan 5 indikator yaitu berwujud, keandalan, ketanggapan, kepastian dan empati. Variabel harga diukur menggunakan 3 indikator yaitu jangkauan harga dengan daya beli konsumen, daya saing harga dengan produk sejenis, dan kesesuaian harga dengan kualitas. Sedangkan untuk variabel kepuasan pelanggan diukur menggunakan 3 indikator yaitu kesesuaian layanan dengan yang diharapkan, kesesuaian layanan dengan tarif yang dibayarkan, kepuasan pelanggan akan layanan yang ditawarkan.

3. Penyusunan kuisioner

Kuisioner yang disusun menggunakan pertanyaan tertutup, dimana pengumpulan data kuisioner dilakukan dengan mendatangi secara langsung para pengguna gojek. Semua varibel yang diambil dalam penelitian ini diiukur dengan menggunakan skala likert poin 1 sampai dengan 5. Adapun sampel yang diambil dalam penelitian ini didasarkan pada purposive sampling dengan ketentuan bahwa para pengguna gojek adalah yang menggunakan jasa goride.

4. Analisa dan pembahasan

Hal ini berkaitan dengan hasil penelitian yang telah diakukan yang didukung oleh data-data valid sehingga menjawab permsalahan yang ada dalam penelitian ini.

5. Kesimpulan dan saran

Pada tahap ini hal yang dilakukan adalah menarik kesimpulan dan memberikan saran atas penelitian yang akan dilakukan selanjutnya.

\section{PEMBAHASAN}

Pada bagian ini, hal pertama yang dijelaskan adalah mengenai statistik deskriptif penelitian yang memuat mengenai karakteristik responden, uji validitas dan reabilitas serta uji asumsi klasik. Hal berikutnya yang dilakukan adalah menguji hipotesis yang dilakukan dengan uji $\mathrm{F}$ dan uji $\mathrm{t}$ untuk melihat pengaruh variabel kualitas pelayanan dan harga terhadap kepuasan pelanggan secara simultan maupun parsial .

\subsection{Statistik Deskriptif Penelitian}

Pengumpulan data dilakukan pada bulan April sampai dengan Agustus 2019. Jumlah kuisioner yang disebarkan adalah 200 orang namun yang mengembalikan kuisioner hanya 109 orang sehingga 
yang menjadi responden dalam penelitian ini. Pada penelitian ini, pembahasan statistik deskriptif dibagi dalam dua bagian. Pertama, pembahasan statistik deskriptif dilakukan untuk menjelaskan dan menggambarkan berbagai karakteristik responden secara keseluruhan berdasarkan jenis kelamin, usia, pendidikan dan penghasilan. Kedua, pembahasan deskriptif juga dilakukan untuk mengetahui sebaran jawaban responden dan seberapa jauh variasi jawaban responden dari setiap variabel penelitian ini.

1. Karakteristik Responden

Adapun yang menjadi responden dalam penelitian ini adalah sebanyak 109 orang yang dapat dilihat pada tabel 1 .

Tabel 1 Karakteristik Responden

\begin{tabular}{|c|c|c|}
\hline Karakteristik & Jumlah & Persentase \\
\hline Jenis kelamin : & & \\
\hline Laki-laki & 73 & $66,97 \%$ \\
\hline Perempuan & 36 & $33,03 \%$ \\
\hline Usia : & & \\
\hline $17-26$ tahun & 13 & $12 \%$ \\
\hline $27-36$ tahun & 41 & $37,6 \%$ \\
\hline $37-46$ tahun & 29 & $26,6 \%$ \\
\hline $47-$ keatas & 26 & $23,8 \%$ \\
\hline Pendidikan & & \\
\hline SD & 8 & $7,3 \%$ \\
\hline SMP & 3 & $3 \%$ \\
\hline SMU/SMK & 24 & $22,01 \%$ \\
\hline Diploma & 32 & $29,3 \%$ \\
\hline Sarjana & 42 & $38,5 \%$ \\
\hline $\begin{array}{l}\text { Penghasilan : } \\
\leq \text { Rp. } 2.500 .000\end{array}$ & 17 & $16 \%$ \\
\hline Rp. $\quad 2.500 .000-$ Rp. & 84 & $77,06 \%$ \\
\hline $\begin{array}{l}5.000 .000 \\
\geq \text { Rp. } 5.000 .000\end{array}$ & 8 & $7,3 \%$ \\
\hline
\end{tabular}

Jika dilihat dari karakteristik responden yang ada dalam penelitian ini dapat dilihat bahwa pengguna transfortasi online lebih banyak dlakoni oleh kaum lakilaki dengan kisaran usia 27 - 36 tahun. Selain itu dilihat dari segi pendidikan dapat dilihat bahwa sarjana paling banyak dengan tingkat penghasilan Rp. $2.500000-\mathrm{Rp}$. 5.000.000,-. Berdasarkan hasil penelitian yang telah dilakukan juga dapat dilihat bahwa kebanyakan pengguna transportasi online dilakukan pada pagi hari saat akan dimulainya jam sekolah atau jam kerja serta pada siang hari menjelang sore dimana kebanyakan pengguna transportasi online untuk pulang ke rumah atau berkunjung ke tempat lain setelah jam sekolah atau jam kerja berakhir.
2. Uji Validitas dan Reabilitas

1) Uji Validitas

Tabe1 2 Uji Validitas

\begin{tabular}{|l|c|r|r|r|}
\hline & $\begin{array}{c}\text { Scale } \\
\text { Mean if } \\
\text { Item } \\
\text { Deleted }\end{array}$ & $\begin{array}{c}\text { Scale } \\
\text { Varianc } \\
\text { e if Item } \\
\text { Deleted }\end{array}$ & $\begin{array}{c}\text { Corrected } \\
\text { Item- } \\
\text { Total } \\
\text { Correlatio } \\
\text { n }\end{array}$ & $\begin{array}{c}\text { Cronbach' } \\
\text { s Alpha if } \\
\text { Item } \\
\text { Deleted }\end{array}$ \\
\hline Pertnyn 1 & 58,2936 & 29,098 &, 303 &, 821 \\
Pertnyn 2 & 58,2661 & 29,067 &, 336 &, 819 \\
Pertnyn 3 & 58,3578 & 28,584 &, 439 &, 814 \\
Pertnyn 4 & 58,3211 & 28,868 &, 391 &, 816 \\
Pertnyn 5 & 58,4404 & 28,027 &, 471 &, 812 \\
Pertnyn 6 & 58,4128 & 28,856 &, 360 &, 818 \\
Pertnyn 7 & 58,5138 & 28,326 &, 392 &, 816 \\
Pertnyn 8 & 58,3578 & 28,917 &, 364 &, 817 \\
Pertnyn 9 & 58,3853 & 27,535 &, 535 &, 808 \\
Pertnyn 10 & 58,5688 & 27,581 &, 456 &, 812 \\
Pertnyn 11 & 58,5780 & 27,117 &, 502 &, 809 \\
Pertnyn 12 & 58,4312 & 28,025 &, 387 &, 817 \\
Pertnyn 13 & 58,6330 & 28,401 &, 325 &, 821 \\
Pertnyn 14 & 58,6055 & 28,667 &, 357 &, 818 \\
Pertnyn 15 & 58,4495 & 28,046 &, 519 &, 810 \\
Pertnyn 16 & 58,6147 & 28,406 &, 415 &, 815 \\
Pertnyn 17 & 58,5872 & 28,282 &, 379 &, 817 \\
Pertnyn 18 & 58,4679 & 27,381 &, 481 &, 811 \\
\hline
\end{tabular}

Berdasarkan hasil uji validitas yang telah dilakukan dapat dilihat Corrected Item-Total Correlation memiliki angka $\geq 0,3$ sehingga dapat dinyatakan bahwa setiap item pertanyaan yang diajukan dalam kuisioner mampu mewakili apa yang menjadi tujuan dalam penelitian ini sehingga dapat dikatakan uji yang dilakukan memiliki validitas yang tinggi.

2) Uji Reabilitas

Berdasarkan hasil uji yang telah dilakukan khususnya mengenai uji reabilitas yang menghasilkan angka cronbanh's alpha sebesar 0,823 dimana angka ini lebih dari 0,7 sehingga dapat dinyatakan bahwa pertanyaan dalam kuisinoer menghasilkan pengukuran realibel. Hal ini mengandung arti bahwa pengukuran yang dilakukan dalam kuisioner dapat dipercaya dan memiliki tingkat kestabilan yang baik sehingga ketika dilakukan pengukuran kembali maka akan dapat diperoleh hasil yang relatif sama. 
3. Uji Asumsi Klasik

1) Multikolinearitas

Tabel 3 Uji Multikolinearitas

\begin{tabular}{|c|r|r|}
\hline \multirow{2}{*}{ Model } & \multicolumn{2}{|c|}{ Collinearity Statistics } \\
\cline { 2 - 3 } & Tolerance & \multicolumn{1}{c|}{ VIF } \\
\hline kualitas layanan &, 884 & 1,132 \\
harga &, 884 & 1,132 \\
\hline
\end{tabular}

a. Dependent Variable: kepuasan pelanggan

Hasil uji multikolinearitas pada tabel di atas terlihat variabel independen tidak memiliki nilai tolerance kurang dari 0,10 dan hasil perhitungan Variance Inflation Factor (VIF) juga tidak menunjukkan nilai VIF lebih dari 10. Maka dapat disimpulkan bahwa model regresi yang diajukan bebas dari multikolinearitas. Begitu pula dengan masing-masing indikator pada variabel independen dapat disimpulkan bebas dari multikolinearitas.

\section{2) Normalitas}

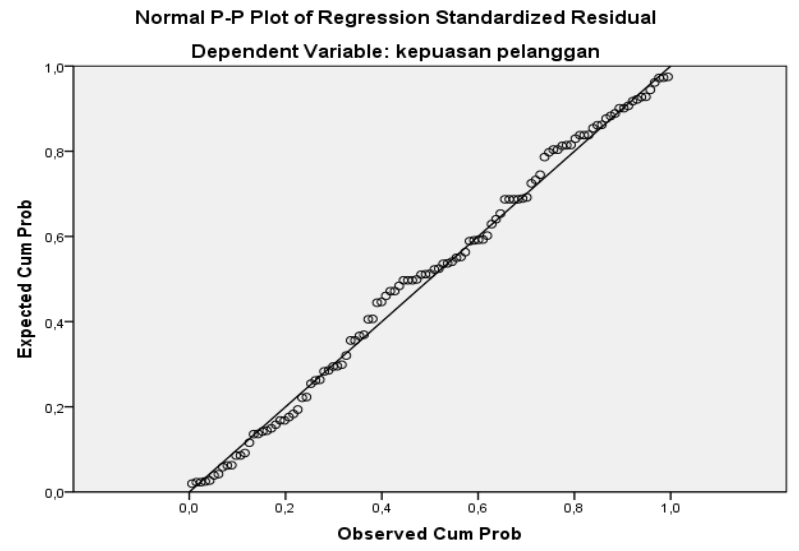

Hasil pengujian dengan analisis grafik plot menunjukkan bahwa model regresi terdistribusi normal, karena titik-titik menyebar di sekitar diagonal serta penyebarannya mengikuti arah diagonal.

\section{3) Autokorelasi}

Uji autokorelasi yang telah dilakukan pada penelitian ini dinilai dari uji Durbin Watson, dimana nilai yang dihasilkan kurang dari 2 maka dapat disimpulkan bahwa model regresi dalam penelitian ini bebas dari autokorelasi. Hal ini menunjukkan bahwa dalam model regresi tidak ada korelasi antara kesalahan pengganggu pada periode $\mathrm{t}$ dengan kesalahan pengganggu pada periode sebelumnya $(\mathrm{t}-1)$.

\subsection{Uji Hipotesis}

Dalam uji hipotesis yang telah dilakukan baik simultan maupun parsial, Berdasarkan hasil pengujian dengan menggunakan alat bantu SPSS diketahui bahwa kepuasan pelanggan dipengaruhi oleh kualitas layanan dan harga sebesar $30,6 \%$ (R Square) sedangkan sisanya dipengaruhi oleh faktor lain yang tidak dijelaskan dalam penelitian ini, hal ini dapat dilihat pada tabel di atas.

1. Uji F

Pengaruh kualitas layanan dan harga terhadap kepuasan pelanggan

Tabel 4. Uji F (Simultan)

\begin{tabular}{|c|r|r|r|r|r|}
\hline Model & $\begin{array}{c}\text { Sum of } \\
\text { Square } \\
\text { s }\end{array}$ & Df & $\begin{array}{c}\text { Mean } \\
\text { Square }\end{array}$ & F & Sig. \\
\hline Regression & 6,985 & 2 & 3,493 & 23,379 &, $000^{\mathrm{a}}$ \\
Residual & 15,836 & 106 &, 149 & & \\
Total & 22,821 & 108 & & & \\
\hline
\end{tabular}

a. Predictors: (Constant), harga, kualitas layanan b. Dependent Variable: kepuasan pelanggan

Berdasarkan taraf signifikansi uji F sebesar 0,000, hal ini membuktikan bahwa kepuasan pelanggan dipengaruhi oleh kualitas layanan dan harga. Kualitas layanan dan harga merupakan varibel yang saling terkait dalam arti bahwa ketika seorang pengguna/pelanggan mengeluarkan sejumlah uang sesuai dengan harga yang telah ditetapkan maka hal ini diharapkan seiring sejalan dengan kualitas layanan yang diberikan. Kebanyakan pengguna/pelanggan menyatakan bahwa harga dan kualitas layanan mampu menggambarkan kepuasan yang diterimanya. Dalam penelitian ini variabel kualitas layanan dan harga yang dijadikan faktor penentu dalam terciptanya kepuasan yang dirasakan oleh pelanggan. Hasil penelitian ini sejalan dengan penelitian yang telah dilakukan (Triantoro, Hadi, and Suryoko 2015) yang menyatakan bahwa kualitas pelayanan dan harga memilih pengaruh terhadap kepuasan pelanggan yang mengisyaratkan bahwa jika kualitas pelayanan dan harga mengalami peningkatan maka akan diikuti dengan kepuasan pelanggannya dan begitu sebaliknya.

2. Uji t

Pengaruh kualitas layanan dan harga terhadap kepuasan pelanggan

Tabel 5 Uji t (Parsial)

\begin{tabular}{|c|c|c|c|c|c|}
\hline \multirow[t]{2}{*}{ Model } & \multicolumn{2}{|c|}{$\begin{array}{l}\text { Unstandardized } \\
\text { Coefficients }\end{array}$} & \multirow{2}{*}{$\begin{array}{c}\begin{array}{c}\text { Standardize } \\
\mathrm{d} \\
\text { Coefficient } \\
\mathrm{s}\end{array} \\
\text { Beta } \\
\end{array}$} & \multirow[b]{2}{*}{$\mathrm{t}$} & \multirow[b]{2}{*}{ Sig. } \\
\hline & B & $\begin{array}{l}\text { Std. } \\
\text { Error }\end{array}$ & & & \\
\hline $\begin{array}{c}\text { (Constant } \\
\text { ) }\end{array}$ & ,570 & ,412 & & 1,383 &, 169 \\
\hline $\begin{array}{l}\text { kualitas } \\
\text { layanan }\end{array}$ & ,615 & , 120 & ,442 & 5,139 &, 000 \\
\hline harga & , 195 & ,079 & ,214 & 2,487 &, 014 \\
\hline
\end{tabular}

a. Dependent Variable: kepuasan pelanggan 
Variabel kualitas layanan yang diukur menggunakan indikator keandalan mengindikasikan bahwa pengguna transportasi online (gojek) dapat mengetahui jika terjadi keteralmbatan dalam pelayanan, serta adanya jaminan bahwa pengemudi gojek juga selalu dilengkapi dengan identitas diri yang mudah untuk ditelusuri dan juga memiliki kemudahan untuk melakukan pemesanan pada aplikasi yang tersedia. Sedangkan dari sisi daya tanggap dapat dilihat bahwa gojek selalu melakukan konfirmasi terkait dengan pemesanan yang telah dilakukan dan pada saat terjadinya proses pengantaran pengemudi gojek juga menanyakan mengenai keluhan yang ada atau mengenai kecepatan kendaraan yang dibawa apakah sesuai dengan keinginan pengguna/pelanggannya. Disamping itu juga pengemudi gojek memiliki empati yang cukup baik terhadap pengguna/pelanggannya, salah satunya ketika mendapat pelanggan yang membawa barang banyak pengemudi gojek tak segan untuk membantu menaikkan barang tersebut ke sepeda motor.

Hasil penelitian mendukung penelitian yang telah dilakukan oleh (Rifaldi, Kadunci, and Sulistyowati 2015) yang menyatakan adanya pengaruh dan hubungan yang kuat antara kualitas pelayanan dan kepuasan pelanggan. Selain itu juga dalam penelitian (Mar'ati and Sudarwanto 2016) menyimpulkan bahwa sebuah layanan sangat diperlukan dalam membentuk kepuasan pelanggan, karena semakin baik pengalaman yang dirasakan pelanggan pada saat melakukan proses penyampaian jasa maka akan semakin tinggi pula kepuasan pelanggan.।

Harga juga merupakan salah satu penentu dalam terciptanya kepuasan pelanggan, dimana harga yang ditawarkan oleh aplikasi gojek dapat dijangkau dan diterima masyarakat pada umumnya. Hal ini berbeda ketika menggunakan ojek manual dimana pengemudinya menetapkan tarif tidak sesuai dengan jarak tempuh. Namun di sisi lain gojek bukan merupakan satu-satunya moda transportasi online sehingga harga yang ditawarkan cukup kompetitif dimana hal tersebut harus seiring sejalan dengan layanan yang ditawarkan agar terjadi kesesuaian antara harga dan kualitas layanan sehingga menimbulkan kepuasan terhadap penggunanya. Hasil penelitian ini khususnya mengenai pengaruh harga terhadap kepuasan pelanggan sejalan dengan penelitian yang dilakukan (Sintya, Intan and Lapian, Joyce 2018) yang menyuratkan bahwa setiap peningkatan dan penurunan kepuasan pelanggan pengguna gojek online pada mahasiswa FEB Unsrat Manado dipengaruhi oleh peningkatan dan penurunan harga.

\section{KESIMPULAN}

Berdasarkan hasil yang diperoleh dapat diketahui bahwa kepuasan pelanggan dipengaruhi oleh harga dan kualitas pelayanan baik secara simultan maupun parsial. Kepuasan yang muncul dapat dilihat dari berbagai segi antara lain yaitu harga dan kualitas pelayanan. Harga yang dibayarkan seorang pelanggan haruslah sejalan dengan kualitas pelayanan yang diterima sehingga berdampak pada kepuasan pelanggan. Dalam hal ini transportasi online menyediakan harga yang cukup terjangkau dan pelayanan yang diberikan juga merupakan salah satu bentuk loyalitas yang diberikan kepada para pelanggannya sehingga tercipta kepuasan dan ketika hal ini selalu seirama maka pra pelanggan akan melakukan pemesanan transportasi online khususnya gojek jika dibandingkan dengan jasa transportasi online lainnya.

\section{SARAN}

Berdasarkan kesimpulan yang telah diperoleh dalam penelitian ini maka saran yang dapat diberikan pada penelitian selanjutnya jika dilakukan adala tidak hanya terfokus pada pengguna transportasi online yang menggunakan jasa goride saja pada aplikasi gojek, sehingga diharapkan pada penelitian berikutnya dapat dibuat pada seluruh pengguna aplikasi yang ada pada transportasi online (gojek). Selain itu penelitian selanjutnya dapat menambah variabel lain selain variabel harga dan kualitas pelayanan, namun apabila tidak menambah variabel maka yang disarankan adalah menambah indikator variabelnya sehingga ketika dilakukan uji dapat menghasilkan pengaruh yang cukup besar ataupun tinggi mengingat dalam penelitian ini terdapat pengaruh yang cukup rendah yaitu hanya sebesar 30,6\% saja serta menggunakan alat analisis yang lain guna memperkuat maupun menentang hasil penelitian. Contohnya dapat menggunakan alat analisis path (jalur) sehingga dapat diketahui kuat dan lemahnya hubungan setiap variabel.

\section{DAFTAR PUSTAKA}

Cahya, Eva. 2015. "Pengaruh Kualitas Produk Dan Harga Terhadap Keputusan Pembelian Smartphone Sony Experia Z Series Di Counter Manina Plaza Surabaya Program Studi S1 Pendidikan Ekonomi."

Kotler and keller. 2009. Manajemen Jasa. Ilmu \& Riset Manajemen. Vol. 3.

Mar'ati, Nafisa, and Tri Sudarwanto. 2016. "Pengaruh Kualitas Layanan Dan Harga Terhadap Kepuasan Pelanggan Jasa Transportasi Ojek Online (Studi Pada Konsumen Gojek Di Surabaya).”

Mardikawati, Woro dan Farida, Naili. 2013. "Pengaruh Nilai Pelanggan Dan Kualitas Layanan Terhadap Loyalitas Pelanggan, Melalui Kepuasan Pelanggan Pada Pelanggan Bus Efisiensi”."

Rifaldi, Kadunci, and Sulistyowati. 2015. "Pengaruh Kualitas Pelayanan Transportasi Online Gojek Terhadap Kepuasan Pelanggan Pada Mahasiswa/i Administrasi Niaga Politeknik Negeri Jakarta” 2.

Sintya, Intan, Lumintang, and S.L.H.V Lapian, Joyce. 2018. "Pengaruh Harga Dan Kualitas Layanan Terhadap Kepuasan Pelanggan Jasa Transportasi Gojek Online Pada Mahasiswa FEB Unsrat Manado." EMBA 6.

Tjiptono. 2008. "Kepuasan Pelanggan. PT. Erlangga, Indonesia." PT. Erlangga, Indonesia 
Http://digilib.unpas.ac.id.

Tjiptono, Fandy. 2014. Pemasaran Jasa. Malang: Bayumedia.

Triantoro, kurnia, Sudharto Hadi, and Sri Suryoko. 2015.

"Pengaruh Kualitas Pelayanan Dan Harga

Terhadap Kepuasan Pelangan Pengguna Jasa Kereta Api Menoreh Kelas Ekonomi Studi Kasus Pada PT Kereta Api Indonesia DAOP IV Semarang." Diponegoro Journal of Social and Political, 1-10.

Utami, Chistrina Widya. 2010. Manajemen Ritel. Jakarta: Salemba Empat. 